\title{
EDITORIAL: OBSERVATIONS ON THE CHANGING SOCIETAL MOSAIC OF NEPAL
}

We have decided to continue on with the idea of giving a thematic title to the Occasional Papers in Sociology and Anthropology by calling the Tenth Volume "Observations on the Changing Societal Mosaic of Nepal". As editors, we deem it essential to declare our reasons for selecting this particular title to represent the papers included in this volume. Any perceptive observer of Nepali society will agree with us that the societal mosaic of Nepal (defined by plurality of religions, caste/ethnic groups, mother tongues spoken, etc.) has never been simple and rigid but has rather been quite complex and fluid or transient all the time. Just as time does not stand still the nature of the social relationships and the resulting structures too have been dynamic - subject to constructions and reconstruction by the agencies inherent in the peoples. A careful reading of the six papers in this collection will reveal that 'change', 'development', and 'transformation' stand out as high priority agenda for contemporary scholars and researchers engaged in the Sociology and Anthropology of Nepal. The preferred vocabulary or the language used by the authors of the six papers in this volume in order to convey the ideas resulting from their respective observations of Nepali social and cultural life may be different. Nonetheless, they all seem to be talking about similar trends and processes in Nepal-that is, transformations, the changing social formations, defining and re-defining of social spaces, etc.

Chaitanya Mishra's article reviews the state of sociological works in Nepal. His diagnosis (primarily based on a review of selected publications in some journals) is that sociology in Nepal remains underdeveloped amidst growth. He cogently argues that the social transformative cauldron in Western Europe in the $19^{\text {th }}$ century created the space for sociological thinking. He then procecds to critically examine the conditions for the emergence as well as florescence of the specific nature of sociology in general and that of Nepal in particular. As a keen observer of Nepali society, Professor Mishra suggests that a better 
sociology of Nepali society and their dynamics is possible by way of embedding the micro-level research agenda within the macro perspectives.

The Norwegian anthropologist. Professor Tone Bleie appears to concur with the suggestion of Professor Mishra with regard to the need for a choice of wider canvas even when discussing apparently localised phenomena. She argues that the unravelling of the intricate interplay between internal and external structural conditions and major national political events over nearly five decades challenges any facile characterisation of the Maoist rebellion as an internal conflict only. The main analytical focus of this article is on the structural conditions and agency actions that resulted in 1996 in a Maoist-led rebellion in Nepal. Using the rights-based perspective, Bleie has discussed how the negotiations over the defining attributes of state authority and of statesociety relations at important conjunctures in Nepal's recent political history are related to political and economic conditions with national, regional and global outreach over many years.

Sondra L. Hauser, in her paper relates the dynamics of three border towns, focusing on Nepal's southem Tarai-a preferred destination of hill migrants in the country. This paper focuses on the contemporary geopolitical reality of the Tarai as a place in which both hill migrants congregate and through which migrants leave Nepal and travel to the Indian plains, in search of work, safety, and opportunity. Hausner critiques the rhetoric of trafficking as the sole measure through which the development industry - both international and national - views the movement of women across the Nepal-India border and opts rather to focus on the labour conditions of voluntary sex workers in Tarai towns. She contends that prostitution in border towns may appear as a localised problem while in reality it not the case.

David Holmberg examines the case of inequality within a supposedly egalitarian Tamang society. He does this by discussing how Tamangs treat the Kamis (Blacksmiths) living together in a hill village. He argues that the framework for ethnographic comparison in South Asia must move beyond the confines of the insular discourse of a Westem/Hindu to include systems like that of the Tamang which treats
Kamis as untouchables while freely inieracting with them in a number of day to day social spheres.

David N. Gellner and Sarah LeVine, examine how caste, class, and gender determine the benefits which monastics in the Theravada community of contemporary Nepal commonly provide for their families of origin. They note that monks, who in recent decades have been recruited mainly from poor families belonging to farming and occupational castes, are more likely to focus on helping their relatives in practical ways, whereas the focus of the nuns, who tend to come from more prosperous higher-caste families, is to provide members of their extended kinship network with opportunities to carn social prestige and spiritual merit through high-profile donations to religious institutions.

Finally, Don Messerschmidt, Gautam Yadama and Bhuvan Silwal, have elaborately discussed the manifestations and impacts of the shortlived National Development Service (NDS) movement that was part of the graduate studies program at Tribhuvan University during the 1970s. The paper also focuses on the rise of civic service and volunteerism in Nepal. The authors argue that the NDS which required all the graduate students to dedicate one year during their Masters degree studies to service in a rural community was considered by many to have been a catalytic social development experiment. They have also pointed out that the NDS had profound effects upon both its participants and host communities. Their analysis reveals that NDS in Nepal in the $1970 \mathrm{~s}$ became the magnet for democratic participation in the absence of other legitimate avenues of democracy during the partyless Panchayat era.

We believe that these articles provide a good sample of contemporary sociological and anthropological research undertaken by scholars in Nepal. As such, the questions and issues raised and discussed in these papers should be of interest to the faculty and students at TU as well as other social scientists in general with an interest on Nepali societal mosaic and the dynamics and or the transformations therein.

\section{Editors}

Ram Bahadur Chhetri

Laya Prasad Uprety

Kathmandu, April 2007 